\title{
Assessment of platyhelminth diversity within amphibians of French Guiana revealed a new species of Nanopolystoma (Monogenea: Polystomatidae) in the caecilian Typhlonectes compressicauda
}

\author{
Louis H. du Preez ${ }^{1}$, Mathieu Badets ${ }^{1}$ and Olivier Verneau ${ }^{1,2,3}$ \\ ${ }^{1}$ Unit for Environmental Sciences and Management, North-West University, Potchefstroom, South Africa; \\ ${ }^{2}$ University of Perpignan, Centre de Formation et de Recherche sur les Environnements Méditerranéens, Perpignan, France; \\ ${ }^{3}$ CNRS, Centre de Formation et de Recherche sur les Environnements Méditerranéens, Perpignan, France
}

\begin{abstract}
An expedition was undertaken to French Guiana in search of amphibian parasites. Of the 23 anuran species collected and screened for polystomes, the toad Rhinella margaritifera (Laurenti) was the sole species found to be infected with a polystome, namely Wetapolystoma almae Gray, 1983. Of the two caecilian species collected, a new species of Nanopolystoma du Preez, Huyse et Wilkinson, 2008 was discovered from the urinary bladder of the aquatic caecilian Typhlonectes compressicauda (Duméril et Bibron). The small size of the mature worm, two non-diverticulated caeca of equal length that are non-confluent posteriorly, vitelline follicles in two dense lateral fields, a single follicular testis in the middle of the body, small ovary and a single operculated egg in utero, vaginae present and the caecilian host allowed the identification of the specimen as Nanopolystoma. Larger body size, hamulus length, egg diameter and occurrence in the caecilian family Typhlonectidae distinguishes the new species from the two other known polystomes in Nanopolystoma; thus, the description of Nanopolystoma tinsleyi sp. n. is provided within this paper.
\end{abstract}

Keywords: Nanopolystoma tinsleyi sp. n., polystome, Cayenne caecilian, Typhlonectidae, Neotropical region

Scientists attending the First World Congress of Herpetology in 1989 first became concerned about a widespread decline in amphibian population numbers (Stuart et al. 2004). Since then, the number of studies and publications on amphibians increased considerably and the number of species known nearly doubled to the current figure of 7044 (Frost 2013). In their comprehensive study to identify biodiversity hotspots for conservation priorities, Meyers et al. (2000) reported on the unique biodiversity of the Neotropical realm and the high levels of endemism. This biogeographical area hosts indeed the highest amphibian diversity in the world with $49 \%$ of all known amphibian species (Stuart et al. 2004, Vredenburg and Wake 2007).

Amphibians serve as hosts to a variety of parasites. For example, the African clawed frog, Xenopus laevis (Daudin), may be infected by no less than 25 different parasite genera from seven higher taxa (Tinsley 1996). Polystomatid flatworms of the class Monogenea Carus, 1863, which comprises 24 genera, are known from a large range of hosts including the Australian lungfish (one genus), amphibians (19 genera), freshwater turtles (three genera) and the hippopotamus (one genus). The vast majority of polystomatids reported are parasite of amphibians, among which 16 genera are from anurans, two from urodelids and one from caecilians.
The Neotropical polystomatid diversity in amphibians includes one species of Mesopolystoma Vaucher, 1981, one Parapseudopolystoma Nasir et Fuentes Zambrano, 1983, 14 Polystoma Fröhlich, 1791, two Riojatrema Lamothe, 1963, one Wetapolystoma Gray, 1993 and two Nanopolystoma du Preez, Huyse et Wilkinson, 2008. With the majority of the world's amphibian diversity in Central and South America (Vredenburg and Wake 2007), this biogeographical area may have played an important role in the evolution of anuran polystomes. According to Bentz et al. (2001, 2006) South America could be the centre of origin for the cosmopolitan and most diversified genus, i.e. Polystoma. In comparison to the South American anuran polystomes that were described mostly in the 1970s and 1980s (see Verneau 2004), Nanopolystoma from caecilians has only recently been described and consists of only two species, i.e. Nanopolystoma brayi du Preez, Huyse et Wilkinson, 2008 from the urinary bladder of Caecilia $\mathrm{cf}$. gracilis Shaw from French Guiana and N. lynchi du Preez, Huyse et Wilkinson, 2008 from the urinary bladder and phallodeum of Caecilia cf. pachynema Günther from an unknown locality in South America.

To increase understanding of global biodiversity, we conducted an expedition to French Guiana to investigate amphibian polystome diversity. In the present paper, a new polystomatid found during this survey is described.

Address for correspondence: L.H. du Preez, School of Biological Sciences, North-West University, Potchefstroom Campus, Private Bag X6001, Potchefstroom 2520, South Africa. Phone: +27 18299 2372; Fax: +27 18299 2372; E-mail: Louis.duPreez@nwu.ac.za 


\section{MATERIALS AND METHODS}

From 9 to 23 April 2012, three areas were surveyed in French Guiana for frogs and caecilians. They included ponds and marshes in and around Cayenne ( $\left.4^{\circ} 52^{\prime} 49^{\prime \prime} ; 52^{\circ} 20^{\prime} 6^{\prime \prime} \mathrm{W}\right)$, a forest pond on the road to Kaw $\left(4^{\circ} 40^{\prime} 12^{\prime \prime} \mathrm{N} ; 52^{\circ} 18^{\prime} 20^{\prime \prime} \mathrm{W}\right)$, and several sites in the tropical forest of the Nouragues National Reserve $\left(4^{\circ} 2^{\prime} 24^{\prime \prime N} ; 52^{\circ} 40^{\prime} 29^{\prime \prime} \mathrm{W}\right)$. Another area was surveyed in December 2011 by Philippe Gaucher, near St. Georges (3०53'11"N; $\left.51^{\circ} 48^{\prime} 6^{\prime \prime} \mathrm{W}\right)$.

Frogs were collected by hand at night with the aid of strong flashlights. They were sorted according to species and placed over night in plastic bags containing some water. The following day the water was poured through two plankton sieves with respective mesh size of 500 and $100 \mu \mathrm{m}$. If polystome eggs were retrieved from a particular species, frog specimens were placed individually in bags and kept one day more for a second round of egg screening. With the exception of endangered species, all infected specimens as well as one representative of each species per locality were euthanised using ethyl-4-aminobenzoate (MS222, Sigma, Johannesburg, South Africa) and dissected for parasites and host tissue collections using a Nikon SMZ 645 microscope (Nikon, Amsterdam, Netherlands).

To search for caecilians, we first dug at numerous places in the forest, however, we did not find any terrestrial caecilians. Our focus then shifted to the aquatic caecilian, Typhlonectes compressicauda (Duméril et Bibron), known to occur in water bodies in French Guiana. Crayfish traps were modified to reduce the entrance size to about $80 \mathrm{~mm}$ in diameter. They were baited with fish or ox liver and set in such a way that part of the trap was above the water to allow captured non-target air breathing animals to surface. They were secured to vegetation and left overnight in about 20 distinct sites.

The GPS coordinates provided only for the localities where caecilians were caught: Site A, a pool of about $30 \mathrm{~m}$ in diameter $\left(4^{\circ} 53^{\prime} 31^{\prime \prime} \mathrm{N} ; 52^{\circ} 20^{\prime} 47^{\prime \prime} \mathrm{W}\right)$ where six traps were set overnight; site B, a big swamp $\left(4^{\circ} 49^{\prime} 23^{\prime \prime} \mathrm{N} ; 52^{\circ} 20^{\prime} 28^{\prime \prime} \mathrm{W}\right)$, where 11 traps were set overnight on a first occasion, and 17 at a later occasion; site $\mathrm{C}$, the downstream part of a big river near St. Georges $\left(3^{\circ} 53^{\prime} 11^{\prime \prime N}\right.$; 51 $\left.48^{\circ} 6^{\prime \prime} \mathrm{W}\right)$, where specimens were collected by P. Gaucher using three funnel traps. Captured caecilians were kept individually in buckets containing water. The procedure for polystome egg screening was the same as described above. Eggs, were rinsed from the $100 \mu \mathrm{m}$ sieve and transferred to a Petri dish for measurements and larval development with the aim to obtain oncomiracidia for morphological description. All specimens were euthanised using MS222 and dissected to verify that they were not infected with subadult polystomes.

The urinary bladder and all reproductive and excretory ducts were thoroughly screened for polystomes. After all visible parasites were removed, the bladder was placed in hot $70 \%$ ethanol and rigorously shaken to detach any small parasites that might have been overlooked. Live parasites were immediately placed in a drop of water on a slide and briefly heated from below with a butane lighter until they relaxed and stopped moving. They were fixed in $10 \%$ neutral buffered formalin under very gentle coverslip pressure. Specimens destined for permanent mounting were stained overnight in a weak acetocarmine solution, then were dehydrated and mounted in Canada balsam, whereas a few subadult specimens earmarked for molecular biology were kept in $70 \%$ ethanol.

\section{RESULTS}

A total of 124 frogs representing seven families and 23 species as well as nine caecilians representing two families and two species were screened for polystomes. Details about species classification and sampling localities are presented in Table 1. A single anuran species was infected, namely Rhinella margaritifera. Among the eight specimens of $T$. compressicauda collected, one at site A, four at site $\mathrm{B}$ and three at site $\mathrm{C}$, a single caecilian from site $\mathrm{B}$ was infected with 14 polystomes. Prevalence was $25 \%$ for site B and $12.5 \%$ for the total sample. The single specimen of $C$. gracilis that was collected by P. Gaucher on a road following heavy rains some weeks prior to our visit was not infected.

\section{Nanopolystoma tinsleyi sp. n.}

Figs. 1, 2, Table 2

Description (based on three egg-producing adult and eight subadult specimens; eggs harvested failed to develop; measurements expressed as range with mean and number of measurements in parentheses). Adult pyriform (Fig. 1). Average body length of mature specimens $2.8-3.1 \mathrm{~mm}$ (2.9 mm). Haptor 684-866 (774) long, 934-948 (941) wide; length: body length ratio of 0.27. Eyespots not observed in adults. Mouth subterminal, ventral, surrounded by false oral sucker. Pharynx spherical. Intestine bifurcate, caeca blind with neither diverticula nor anastomoses, left and right caeca of almost equal length, extending laterally along full length of body proper and extending to posterior medial position just anterior to haptor where two arms come very close to each other but do not join.

Genitointestinal canal present just before entry of posterior vitelline duct, connecting oviduct to caecum. Testis single, prominent, follicular, postovarian, median in midbody extending laterally to vitellarium, in length about $25 \%$ of body proper, dense masses of sperm in between testicular follicles (Fig. 1). Vas deferens widens anteriorly forming seminal vesicle, narrows at genital bulb to open at common genital opening. Genital bulb just behind intestinal bifurcation, armed with 16 genital spines; genital spine length 20 (19-20), strongly curved with branched root on proximal ends and sharp point distally pointing outwards, arranged in circle.

Two prominent vaginae, on lateral margins about one third from anterior end at level of ovary; vaginal ducts descending to respective vitelline ducts. Main left and right vitelline ducts join medially to form vitelline reservoir with posterior duct connecting to oviduct. Vitellarium follicular, dense, from position of intestinal bifurcation confined to 2 lateral fields extending posteriorly to end of body proper, giving impression of a peripheral ring of vitelline follicles.

Ovary prominent, curved oval, to one side of body at level of egg; developing oocytes from tiny dots gradually increasing in size to fully formed oocytes. Oviduct leaves 
Table 1. List of anurans and caecilians screened for polystomes.

\begin{tabular}{|c|c|c|c|}
\hline Family & Species & Locality & $\begin{array}{l}\text { No. host } \\
\text { examined }\end{array}$ \\
\hline \multirow[t]{7}{*}{ Bufonidae } & Rhaebo guttatus (Schneider) & Nouragues & 1 \\
\hline & $\begin{array}{l}\text { Rhinella aff. castaneotica } \\
\text { (Caldwell) }\end{array}$ & Nouragues & 3 \\
\hline & R. marina (Linnaeus) & Cayenne & 1 \\
\hline & R. marina & Nouragues & 2 \\
\hline & R. 'margaritifera' (Laurenti) & Cayenne & 6 \\
\hline & R. 'margaritifera" & Nouragues & 33 \\
\hline & $\begin{array}{l}\text { R. lescurei Fouquet, Gaucher, } \\
\text { Blanc et Vélez-Rodrigues }\end{array}$ & Nouragues & 1 \\
\hline Centrolenidae & Vitreorana ritae (Lutz) & Nouragues & 1 \\
\hline \multirow[t]{2}{*}{ Craugastoridae } & $\begin{array}{l}\text { Pristimantis chiastonotus } \\
\text { (Lynch et Hoogmoed) }\end{array}$ & Nouragues & 1 \\
\hline & $\begin{array}{l}\text { P. zeuctotylus } \\
\text { (Lynch et Hoogmoed) }\end{array}$ & Nouragues & 3 \\
\hline \multirow[t]{3}{*}{ Dendrobatidae } & $\begin{array}{l}\text { Allobates aff. femoralis } \\
\text { (Boulenger) }\end{array}$ & Nouragues & 1 \\
\hline & $\begin{array}{l}\text { A. granti Kok, MacCulloch, } \\
\text { Gaucher, Poelman, Bourne, } \\
\text { Lathrop et Lengle }\end{array}$ & Nouragues & 1 \\
\hline & Dendrobates tinctorius (Cuvier) & )Nouragues & 7 \\
\hline \multirow[t]{11}{*}{ Hylidae } & $\begin{array}{l}\text { Dendropsophus nanus } \\
\text { (Boulenger) }\end{array}$ & Cayenne & 4 \\
\hline & D. nanus & Kaw forest & 3 \\
\hline & $\begin{array}{l}\text { Hypsiboas cf. cinerascens } \\
\text { (Spix) }\end{array}$ & Nouragues & 4 \\
\hline & H. punctatus (Schneider) & Cayenne & 3 \\
\hline & H. punctatus & Kaw forest & 3 \\
\hline & $\begin{array}{l}\text { Osteocephalus cf. taurinus } \\
\text { Steindachner }\end{array}$ & Nouragues & 1 \\
\hline & $\begin{array}{l}\text { Phyllomedusa aff. tomopterna } \\
\text { Duméril et Bibron }\end{array}$ & Kaw forest & 6 \\
\hline & Scinax boesemanni (Goin) & Cayenne & 6 \\
\hline & S. boesemanni & Kaw forest & 1 \\
\hline & S. ruber (Laurenti) & Nouragues & 1 \\
\hline & $\begin{array}{l}\text { Trachycephalus coriaceus } \\
\text { (Peters) }\end{array}$ & Kaw forest & 13 \\
\hline \multirow[t]{4}{*}{ Leptodactylidae } & $\begin{array}{l}\text { Leptodactylus pentadactylus } \\
\text { (Laurenti) }\end{array}$ & Cayenne & 10 \\
\hline & L. pentadactylus & Nouragues & 1 \\
\hline & L. podicipinus (Cope) & Kaw forest & 2 \\
\hline & L. podicipinus & Nouragues & 1 \\
\hline \multirow[t]{2}{*}{ Pipidae } & Pipa aspera Müller & Nouragues & 1 \\
\hline & P. pipa (Linnaeus) & Cayenne & 3 \\
\hline \multirow[t]{2}{*}{ Typhlonectidae } & Caecilia gracilis Shaw & Kaw forest & 1 \\
\hline & Typhlonectes compressicauda ${ }^{2}$ & Cayenne & 8 \\
\hline
\end{tabular}

six specimens infected with Wetapolystoma almae Gray, $1993 ;{ }^{2}$ one specimen infected with Nanopolystoma tinsleyi sp. n.

ovary, ascends and receives duct from vitelline reservoir, forms ootype, surrounded by Mehlis' gland. Uterus short, anterior to ovary, containing a single oval egg. Eggs 236-260 (249) × 168-193 (183; n = 9), yellowish-tan, operculate, oval, with operculated end flattened; no indication of intrauterine development. Oncomiracidium not known.

Haptor with 3 pairs of laterally located suckers, diameter 164-187 (176), size and shape variable in adult specimens; hamulus body robust with deep cut between two roots (Fig. 2A), inner length 25-118 (66), outer length 133-175 (164), recurved hook 24-33 (28). In one of paratypes, one hamulus deformed with a second guard (Fig. 2A). Spherical sclerite droplets associated with ha-

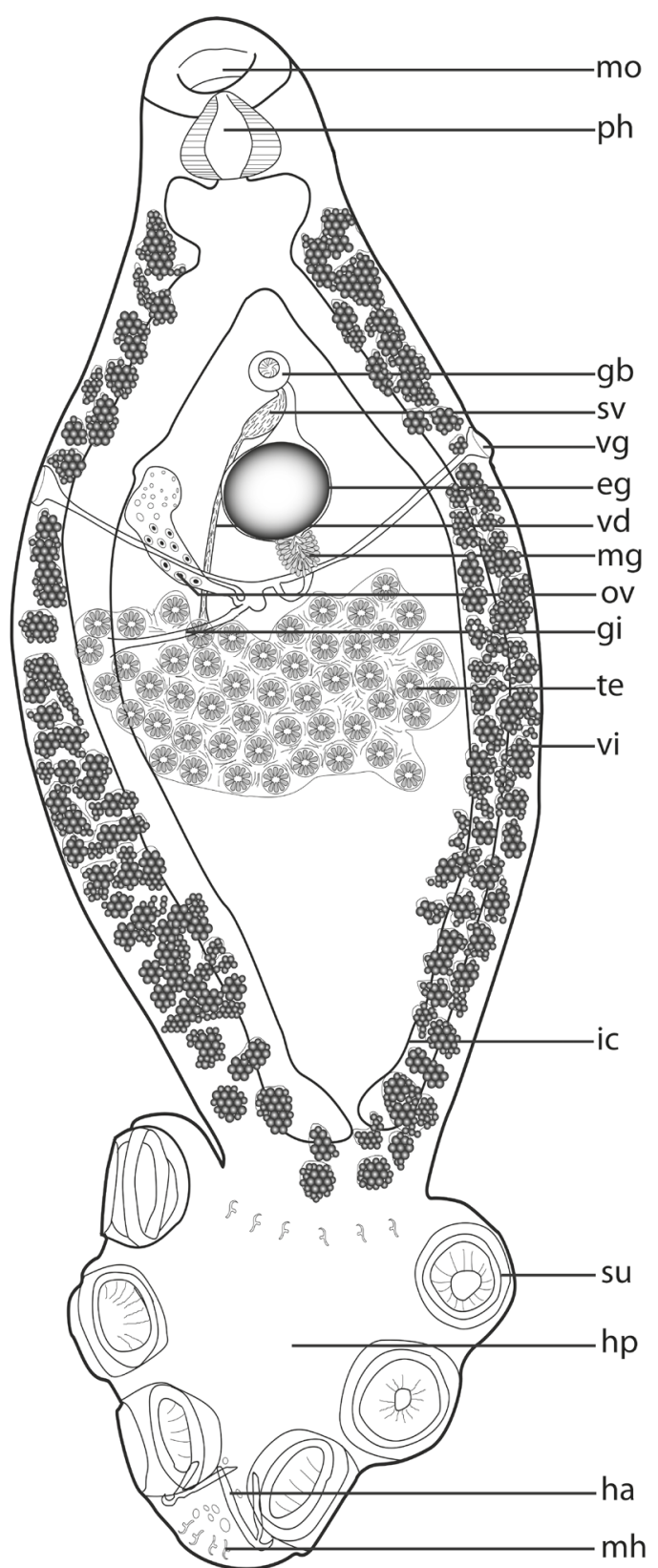

Fig. 1. Nanopolystoma tinsleyi sp. n. from Typhlonectes compressicauda. Ventral view of holotype (NMB P357). Abbreviations: eg - egg; gb - genital bulb; gi - genitointestinal canal; ha - hamulus; hp - haptor; ic - intestinal caecum; mg - Mehlis' gland; mh - marginal hooklets; mo - mouth; ov - ovary; ph - pharynx; su - sucker; sv - seminal vesicle; te - testis; vd - vas deferens; vg - vagina; vi - vitellarium.

muli. Placement of marginal hooklets as for other polystomes: pairs 1 and 2 most posterior between pairs 3, 4 and 5 at bases of suckers and pairs 6-8 anterior in haptor between anterior most suckers. Marginal hooklets all similar in shape and length (Fig. 2B), measuring 18.4-20.3 (19.6).

Type host: Typhlonectes compressicauda (Duméril et Bibron).

Type 1ocality: Swamp close to Cayenne, French Guiana 
Table 2. Diagnostic measurements for Nanopolystoma tinsleyi sp. n., N. brayi and N. lynchi. Range with mean in parentheses are given in micrometres $(\mu \mathrm{m})$, except for body length.

\begin{tabular}{|c|c|c|c|c|}
\hline Characteristics & \multicolumn{2}{|c|}{ Nanopolystoma tinsleyi sp. $\mathrm{n}$. } & $\begin{array}{l}N . \text { brayi } \\
\text { mature }\end{array}$ & $\begin{array}{l}N . \text { lynchi } \\
\text { mature }\end{array}$ \\
\hline Number of specimens & 8 & 3 & 4 & 8 \\
\hline Body length (mm) & $0.7-2.1(1.6)$ & $2.8-3.1(2.9)$ & $1.1-1.4(1.2)$ & $1.4-2.0(1.7)$ \\
\hline Maximum width & $346-703(549)$ & $1076-1153(1123)$ & $543-572(555)$ & $631-737(690)$ \\
\hline Haptor length & $273-502(425)$ & $684-866(774)$ & $398-446(415)$ & $504-592(561)$ \\
\hline Haptor width & $365-695(545)$ & $934-948(941)$ & $388-529(457)$ & $552-630(590)$ \\
\hline Width at vagina & $452-694(534)$ & $971-1060(1013)$ & $514-534(529)$ & $630-698(661)$ \\
\hline False oral sucker width & $76-137(102)$ & $167-180(175)$ & - & - \\
\hline Pharynx length & $101-118(113)$ & $161-190(174)$ & $60-86(68)$ & $137-175(152)$ \\
\hline Pharynx width & $108-153(138)$ & $197-248(218)$ & $101-108(106)$ & $156-199(184)$ \\
\hline Ovary length & $129-228(184)$ & $275-376(328)$ & $106-130(119)$ & $132-204(173)$ \\
\hline Ovary width & $35-58(46)$ & $81-101(88)$ & $55-67(62)$ & $65-96(83)$ \\
\hline Uterine egg length & - & $236-260(249)$ & $182-238(221)$ & $151-262(218)$ \\
\hline Uterine egg width & - & $168-193(183)$ & $110-115(114)$ & $110-173(123)$ \\
\hline Testis length & $81-486(279)$ & $385-577(492)$ & - & - \\
\hline Testis width & $166-485(390)$ & $674-861(764)$ & - & - \\
\hline Genital bulb width & - & $68-71(70)$ & 91-108 (97) & $74-84(78)$ \\
\hline Genital spine number & - & 16 & $16-19$ & $10-12$ \\
\hline Genital spine length & - & $19-20(20)$ & $20-22(21)$ & $18-19(19)$ \\
\hline Haptoral sucker diameter & $81-133(109)$ & $164-187(176)$ & $122-139(129)$ & $139-182(162)$ \\
\hline Hamulus length & $90-136(115)$ & $133-175(164)$ & $74-110(95)$ & $81-121(104)$ \\
\hline Hamulus hook & $21-29(23)$ & $24-33(28)$ & 26 & $26-29(28)$ \\
\hline Marginal hooklet length & - & $18.4-20.3(19.6)$ & $19-20(20)$ & $17-19(18)$ \\
\hline
\end{tabular}

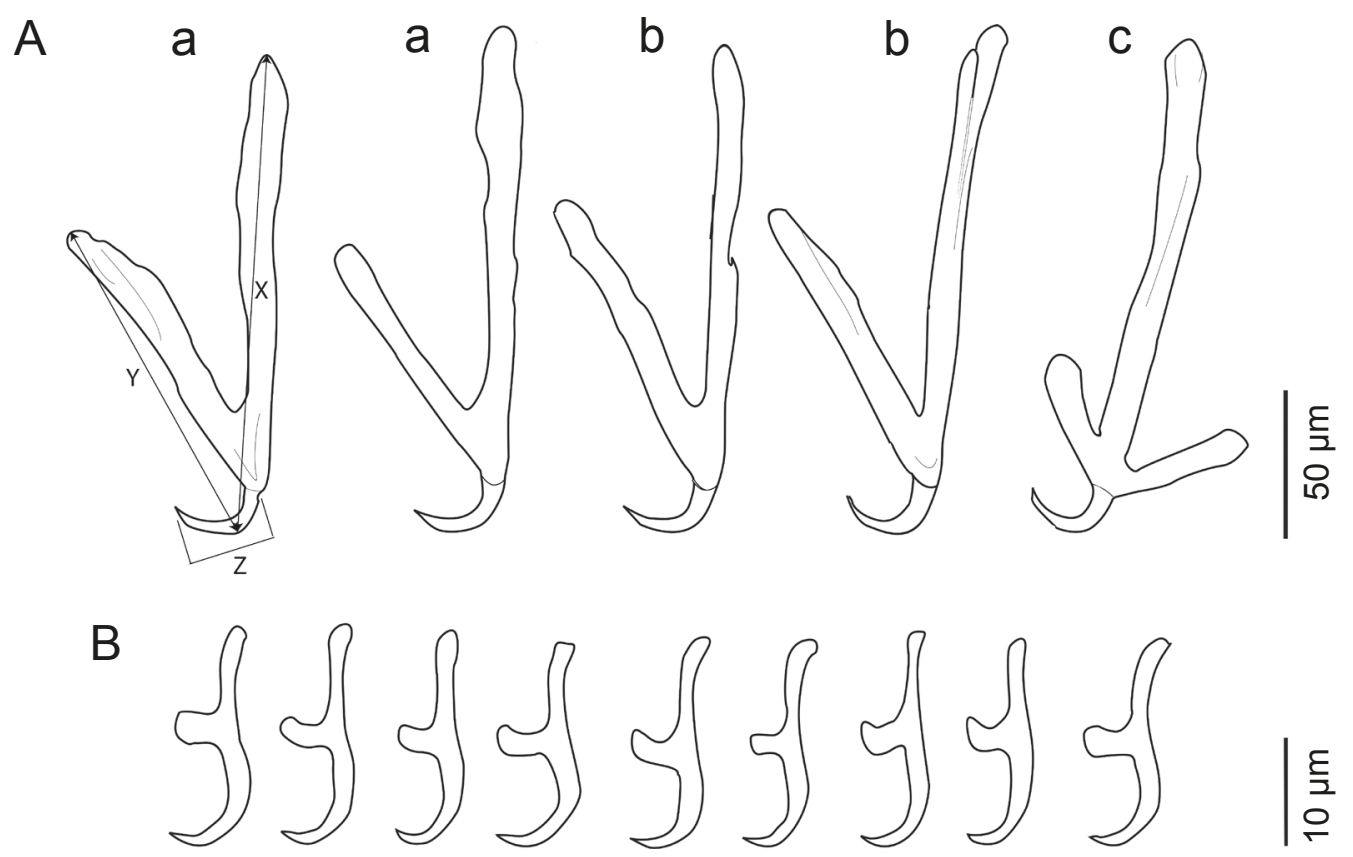

Fig. 2. Nanopolystoma tinsleyi sp. $\mathrm{n}$. from Typhlonectes compressicauda.A - hamulus from holotype NMB P357 (a) and paratypes NMB P 358-360 (b, c); B - marginal hooklets 1 from holotype and paratypes. Abbreviations: X - outer length; Y - inner length; $\mathrm{Z}$ - hook length.

(449'23"N; 52²0'28"W; 28 m a.s.1.).

$\mathrm{S}$ i t e : Urinary bladder.

Deposition of specimens: Eleven worms of which three were sexually mature were mounted as permanent slides. The remaining three subadult specimens were fixed for further molecular studies. Deposited specimens include the holotype (NMB P357) and three paratypes (NMB P358-360) in the Parasitic Worm Collection, National Museum, Bloemfontein, South Africa and one paratype (IPCAS M-556) in the Helminthological Collection, Institute of Parasitology, Biology Centre of ASCR, České Budějovice, Czech Republic. The remainder of specimens was deposited in the collec- 
tion of LDP at the North-West University, South Africa.

Etymology: This species is named after Dr. Richard Tinsley in acknowledgement of his tremendous contribution to knowledge of polystomatid flatworms.

Remarks. With an average total length of $2.9 \mathrm{~mm}$ Nanopolystoma tinsleyi sp. $\mathrm{n}$. is about double the size of the other two known species, specifically $1.2 \mathrm{~mm}$ for $N$. brayi and $1.7 \mathrm{~mm}$ for $N$. lynchi (Table 2). This significant difference in the total length applies for most body measurements. Where the hamulus hook length is basically identical for $N$. tinsleyi, N. brayi and N. lynchi, the total hamulus length for $N$. tinsleyi, i.e. $164 \mu \mathrm{m}$ in average (133-175 $\mu \mathrm{m})$, is significantly greater than in $N$. brayi, i.e. $95 \mu \mathrm{m}(74-110 \mu \mathrm{m})$ and $N$. lynchi, i.e. $104 \mu \mathrm{m}$ (81-121 $\mu \mathrm{m}$ ) (Table 2). For both N. brayi and N. lynchi, the hook length expressed as a percentage of the hamulus length was $27 \%$, whereas it is only $17 \%$ for $N$. tinsleyi. The egg length for $N$. tinsleyi, i.e. $249 \mu \mathrm{m}(236-260 \mu \mathrm{m})$, is greater than in $N$. brayi, i.e. $221 \mu \mathrm{m}(182-238 \mu \mathrm{m})$, and $N$. lynchi, i.e. $218 \mu \mathrm{m}(151-262 \mu \mathrm{m})$, though it is not significant. In contrast, egg width of 183 (168-193) for $N$. tinsleyi is significantly larger than in $N$. brayi, i.e. $114 \mu \mathrm{m}(110-115 \mu \mathrm{m})$ and substantially larger than in $N$. lynchi, i.e. $123 \mu \mathrm{m}(110-173 \mu \mathrm{m})$ (Table 2). The genital spine number of 16 for $N$. tinsleyi does separate it from N. lynchi with 10-12 genital spines (Table 2).

Finally, even if it is tentative to consider the host species as a criterion to describe new parasite species, T. compressicauda, which belongs to the Typhlonectidae, differs in morphological, biological (Wilkinson and Nussbaum 2006) and phylogenetic (Zhang and Wake 2009, Pyron and Wiens 2011) features from Caecilia gracilis and Caecilia cf. pachynema (Caeciliidae), which are the respective hosts for N. brayi and for N. lynchi.

Although unpublished sequences 18S of rDNA (GenBank Acc. No. KM282386), 28S rDNA (GenBank Acc. No. KM282387) and coxl (GenBank Acc. No. KM282388) of $N$. tinsleyi confirmed that the genus $\mathrm{Na}$ nopolystoma is a valid taxon, the lack of DNA for the two other known species in the genus prevented to unravel their phylogenetic relationship.

\section{DISCUSSION}

Nanopolystoma tinsleyi sp. n. fits the generic criteria reported by du Preez et al. (2008), who erected $\mathrm{Na}$ nopolystoma. However, since all specimens of $N$. tinsleyi are bigger than those of $N$. brayi and $N$. lynchi, the criterion of "small ovoid worms, $\mathrm{ca}$ 1-2 mm" as stated by du Preez et al. (2008) should be modified to read "up to about $3 \mathrm{~mm}$ ". Although $N$. tinsleyi is on average double the size of the other known species in the genus, it is still among the smallest of the Polystomatidae. The majority of polystomes are in the order of $4-8 \mathrm{~mm}$ in length with Oculotrema Stunkard, 1924 the biggest and reaching a length of $32.5 \mathrm{~mm}$ (du Preez and Moeng 2004). It does, however, exceed the maximum length of $3.0 \mathrm{~mm}$ for
Madapolystoma du Preez, Raharivololoniaina, Verneau, Vences, 2010. The absence of a uterus implies that eggs cannot be accumulated and thus intrauterine development is not possible. Therefore, the presence of adult and subadult specimens of $N$. tinsleyi in the same host suggests that adult hosts can be re-infected. In a vast swamp the chances of a free-swimming oncomiracidium to locate a suitable host is so remote that one can assume that host behaviour will be instrumental in facilitating infection and reinfection. It was reported that $T$. compressicauda spends daytime in a communal burrow and only leaves at night to feed (AmphibiaWeb 2014). This might provide the opportunity for polystome eggs to be deposited and to hatch in the burrow, which may facilitate infection of a community of caecilians. However, this needs to be further investigated.

Hamuli of $N$. tinsleyi as well as those of $N$. brayi and $N$. lynchi have the same basic shape with a very deep incision between the handle and the guard. In the original description of both $N$. brayi and N. lynchi, most of the hamuli were not oriented flat (du Preez et al. 2008). However, the two flat oriented hamuli reported for $N$. lynchi (see du Preez et al. 2008) had the same shape as reported here for N. tinsleyi. The incision between the handle and the guard of the hamuli is the deepest reported for any known polystome. Euzet et al. (1974) recognised the potential of the hamulus shape as a taxonomic character for polystomes and took four measurements per hamulus. Murith (1981) separated several African polystomes based on the hamulus shape. Since hamulus shape varies considerably between different polystome genera, an in-depth study on the variation and significance of this morphological structure is needed.

We have very good reasons to believe that the 108 species of amphibian polystomes currently known underrepresent global polystome diversity. Du Preez (1996) reported 27 anuran species from Vernon Crookes Reserve, a tiny coastal reserve in the Kwazulu-Natal Province of South Africa. Of these, no less than 10 species hosted polystomes. Du Preez (2011) reported that 11 of the 49 species of grass frog Ptychadena Boulenger known from Africa are hosts for polystomes. Since several species of Ptychadena have not yet been screened for polystomes, it is likely that more polystome species remain to be discovered. In a recent study conducted in the Okumu Reserve in Nigeria, researchers revealed no less than ten different polystome species including one undescribed species from ten different host species in a fairly small geographical area within the National Park (M.S.O. Aisien, University of Benin City, Benin City, Nigeria - pers. comm.). Currently, there are 51 polystome species known from amphibians in the Ethiopian Realm and 21 from the Neotropical Realm. Though we found only two infected amphibian species during our field investigations in French Guiana (Table 1), we can assume that the exceptionally rich amphibian fauna of the Neotropical Realm may be host to a larger diversity of polystomes. 
The Polystomoidinae includes the three known polystome genera from chelonians, namely Polystomoides Ward, 1917, Polystomoidella Price, 1939 and Neopolystoma Price, 1939, as well as Nanopolystoma based on morphological similarities that it shares with the chelonian polystomes (see du Preez et al. 2008). All known species of the Polystomoidinae also have a non-sanguinivorous diet and it is believed that they feed on mucous and/or epithelial cells (Allen and Tinsley 1989). Du Preez and Moeng (2004) stated that an epithelial diet, which is common in polystomes of chelonians, Australian lungfish and hippopotamus, might reflect a common ancestry. Verneau et al. (2002) showed, based on a molecular phylogenetic study of polystomes covering 11 polystome genera, that chelonian and amphibian polystomes form two distinct sister clades. Because the lack of blood pigments in the intestinal caeca of Nanopolystoma also indicates a non- sanguinivorous diet, it should therefore be very interesting to investigate its phylogenetic position within the Polystomatidae as it might provide insights into the origin of chelonian polystomes (see Verneau et al. 2002). Examining Nanopolystoma oncomiracidia might also supply interesting features on polystome evolution as the ciliated cell pattern and chaetotaxy are distinct for polystome genera.

Acknowledgements. We wish to thank Philippe Gaucher and Antoine Fouquet for their assistance during fieldwork and their expertise in amphibian systematics as well as John Malone and Valerie Clarke for commenting on the manuscript. We acknowledge Tomáš Scholz and the reviewers for their constructive remarks on the manuscript, and the National Research Foundation of South Africa for financial support. Any opinion, findings and conclusions or recommendations expresses in this material are those of the authors and therefore the NRF does not accept any liability in regard thereto.

\section{REFERENCES}

Allen K.M., Tinsley R.C. 1989: The diet and gastrodermal ultrastructure of polystomatid monogeneans infecting chelonians. Parasitology 98: 265-273.

AmphibiaWeb. Information on Amphibian Biology and Conservation 2014. Web application; Berkeley, California: AmphibiaWeb, http://amphibiaweb.org, 01/2014.

Bentz S., Leroy S., du Preez L.H., Mariaux J., Vaucher C., Verneau O. 2001: Origin and evolution of African Polystoma (Monogenea: Polystomatidae) assessed by molecular methods. Int. J. Parasitol. 31: 697-705.

Bentz S, Sinnappah-Kang N.D., Lim L.-H.S., Lebedev B., Combes C., Verneau O. 2006: Historical biogeography of amphibian parasites, genus Polystoma (Monogenea: Polystomatidae). J. Biogeogr. 33: 742-749.

Euzet L., Combes C., Batchyarov G. 1974: Sur un nouveau Polystomatidae européen parasite de l'amphibien Bufo viridis Laur. Vie Milieu 24: 129-139.

Frost D.R. 2013: Amphibian Species of the World: an Online Reference. Version 5.6. Electronic Database, http://research. amnh.org/herpetology/amphibia/index.html, 01/2013, American Museum of Natural History, New York.

Murith, D. 1981: Contribution à l'étude de la systématique des polystomes (Monogènes, Polystomatidae) parasites d'amphibiens Anoures de basse Côte-d'Ivoire. Rev. Suisse Zool. 88: 475-533.

Myers N., Mittermeier R.A., Mittermeier C.G., Da FonSECA G.A.B., Kent J. 2000: Biodiversity hotspots for conservation priorities. Nature 403: 853-858.

Du Preez L.H. 1996: Anuran community structure in the Vernon Crookes Nature Reserve. Madoqua 19: 25-29.

Du Preez L.H. 2011: Polystoma vernoni sp. n. (Monogenea: Polystomatidae) from the sharp nosed grass frog Ptychadena oxyrhynchus (Smith, 1849) in South Africa. J. Helminthol. 85: 294-299.

Du Preez L.H., Moeng I.A. 2004: Additional morphological information on Oculotrema hippopotami Stunkard, 1924 (Monogenea: Polystomatidae) parasitic on the African hippopotamus. Afr. Zool. 39: 225-233. du Preez L.H., Raharivololoniaina L., Verneau O., VencES M. 2010: A new genus of polystomatid parasitic flatworm (Monogenea: Polystomatidae) without free-swimming life stage from the Malagasy poison frogs. Zootaxa 2722: 54-68.

Du Preez L.H., Wilkinson M., Huyse T. 2008: The first record of polystomes (Monogenea: Polystomatidae) from caecilian hosts (Amphibia: Gymnophiona) with the description of a new genus and two new species. Syst. Parasitol. 69: 201-209.

Pyron R.A., Wiens J.J. 2011: A large-scale phylogeny of Amphibia including over 2800 species, and a revised classification of extant frogs, salamanders, and caecilians. Mol. Phylogenet. Evol. 61: 543-583.

Stuart S.N., Chanson J.S., Cox N.A., Young B.E., RoDríguez A.S.L., Fischman D.L., Waller R.W. 2004: Status and trends of amphibian declines and extinctions worldwide. Science 306: 1783-1786.

Tinsley R.C. 1996: Parasites of Xenopus. In: R.C. Tinsley and H.R. Kobel. (Eds.), The Biology of Xenopus. Clarendon Press, Oxford, pp. 233-261.

Verneau O. 2004: Origine et évolution des monogènes Polystomatidae, parasites d'amphibiens et de chéloniens d'eau douce. HDR thesis, Université de Perpignan, 131 pp.

Verneau O., Bentz S., Sinnappah N.D., du Preez L.H.,Whittington I., Combes C. 2002: A view of early vertebrate evolution inferred from the phylogeny of polystome parasites (Monogenea: Polystomatidae). Proc. R. Soc. Lond. Ser. B 269: 535-543.

VRedenburg V.T., Wake D.B. 2007: Global declines of amphibians. In: S.A. Levin (Ed.), Encyclopedia of Biodiversity Online Update 1. Elsevier Ltd., Oxford, pp. 1-9.

Wilkinson M., Nussbaum R.A. 2006: Caecilian phylogeny and classification. In: J.-M. Exbrayat (Ed.), Reproductive Biology and Phylogeny of Gymnophiona (Caecilians). Science Publishers, Enfield, New Hampshire, pp. 39-78.

ZhaNG P., WaKe M.H. 2009: A mitogenomic perspective on the phylogeny and biogeography of living caecilians (Amphibia: Gymnophiona). Mol. Phylogenet. Evol. 53: 479-491. 